DOI: http://dx.doi.org/10.33846/hn20613

http://heanoti.com/index.php/hn

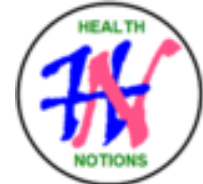

RESEARCH ARTICLE

URL of this article: http://heanoti.com/index.php/hn/article/view/hn20613

\title{
Quality of CT Scan Service to Patient Satisfaction in Radiology Unit of "Harapan Keluarga" Hospital
}

\author{
Kendra Wardhani Khrisnawathy ${ }^{1(\mathrm{CA})}$ \\ ${ }^{1(\mathrm{CA})}$ Department of Health Administration and Policy, Faculty of Public Health, Universitas Airlangga, \\ Indonesia; ekendra9@gmail.com (Corresponding Author)
}

\begin{abstract}
The CT scan inspection data from the Radiology unit at Harapan Keluarga hospital showed a decrease in the number of visits in 2014, is 457 patients with a target of 550 patients. The purpose of this study is to provide an overview of the quality of CT scan services on the level of patient satisfaction. This research used descriptive survey method. This research was conducted from November to December 2015 in Radiology Unit of Harapan Keluarga Hospital of Mataram City. Sample size in this study was 93 patients in period of 2012-2014, selected by using purposive sampling. Data collection method used is questionnaire or questionnaire. Primary data obtained through interviews or filling questionnaires given to respondents. The result showed that the quality of service to patient satisfaction CT scan from aspect tangible good service (86.0) good service reliability (64.5\%), good service assurance (74.2\%), good service responsiveness (61.3\%) and good service empathy (50.5\%). Can be concluded based on patient satisfaction items that CT scan service has good category. The need to make the rules/SOP of CT scan patients concerning alertness and awareness of officers to be available if needed patients, conduct socialization to provide information about the program of promotional activities in patients.
\end{abstract}

Keywords: satisfaction; quality service; CT scan; inspection

\section{INTRODUCTION}

The hospital is a health care organization that has a social mission to serve and heal the sick without distinguishing its socio-economic status. But on the other hand, the hospital also functions as a business, because besides health services there are also many other businesses, both medical and nonmedical, and a shelter of various medical, paramedical, and non-medical professionals who do the work to earn a living ${ }^{(1)}$.

Hospitals in Indonesia, especially the private sector have been doing marketing such as promotions and advertaising with various ways to attract customers. This resulted in increased number of visits to the hospital conducting the marketing activities, and the increase in hospital revenue and giving the impression of a good image for the hospital doing the marketing ${ }^{(2)}$.

Harapan Keluarga Hospital of Mataram is a class C hospital with Permission Number 824/XII/2012 which commenced operations on 24 November 2011 and has a capacity of 142 beds equipped with Emergency, Outpatient, Medical Support, Inpatient, Pharmacy, Operations and ICU facilities. In order to realize one mission of Harapan Keluarga Hospital that is in providing quality service and technology, the Harapan Keluarga Hospital has a Radiology Unit as a medical supporter who provides inspection services with inspection results in the form of photographs or drawings to help Doctors who treat patients in diagnosis enforcement. Referring to one of these missions, Radiology Unit of Harapan Keluarga Hospital has the latest technological device that is CT scan 128 Slice that is able to present a detailed picture of almost all organs of the body including blood vessels. The technology device is a superior product of family hospital because it has not been found in other hospital in West Nusa Tenggara province especially Mataram city.

Based on Hospital Information System of Health Department in 2015 obtained data of medical support facility of MRI and CT scan at Radiology unit at Mataram area hospital, it is known that Harapan Keluarga Hospital has medical support facility CT scan with latest technology than hospital others. Although, it has excellent products with the latest technology tools in NTB province especially Mataram city. Based on the CT scan data from the Radiology unit at Harapan Keluarga Hospital showed a decrease in the number of visits in 2014 is 457 patients with a target of 550 patients. 
Many of the possible factors behind the decline in patient visits for CT scan in 2014 include the lack of information to the public about the benefits of the latest technology products in Radiology Unit such as promo discount provided by Harapan Keluarga hospital, the presence of competitors that appear with more tariff low technology, but the technology under the technology owned by Harapan Keluarga Hospital, and the lack of good relationships with the radiologist referral referrer and poor service quality can be the main trigger factor of the decrease in the number of visits. The purpose of this study is to provide an overview of the quality of CT scan services on the level of patient satisfaction.

\section{METHODS}

This study used descriptive survey method that aim to provide an overview of patient satisfaction about CT scan service at Radiology Unit of Harapan Keluarga Hospital. This research was conducted from November to December 2015 in Radiology Unit of Harapan Keluarga Hospital of Mataram City. The population in this study were all patients who performed CT scan in Radiology Unit of Harapan Keluarga Hospital period 20122014 and as sample of some patients who performed CT scan in Radiology Unit of Harapan Keluarga hospital period 2012-2014 which was chosen by using purposive sampling method amounted 93 patients. Data collection method used was questionnaire. The type of data used was the primary data obtained through interviews or filling questionnaire given to the respondents and data analysis was done descriptively.

\section{RESULTS}

\section{Tangible}

Table 1. Distribution of patient based on tangible aspects of CT scan service in Harapan Keluarga Hospital

\begin{tabular}{|c|c|c|c|c|c|c|c|c|c|c|c|}
\hline \multirow{2}{*}{ Number } & \multirow{2}{*}{ Statement } & \multicolumn{2}{|c|}{ SD } & \multicolumn{2}{|c|}{$\mathrm{D}$} & \multicolumn{2}{|c|}{$\mathrm{A}$} & \multicolumn{2}{|c|}{ SA } & \multicolumn{2}{|c|}{ Total } \\
\hline & & $\mathrm{n}$ & $\%$ & $\mathrm{n}$ & $\%$ & $\mathrm{n}$ & $\%$ & $\mathrm{n}$ & $\%$ & $\mathrm{n}$ & $\%$ \\
\hline 1. & $\begin{array}{l}\text { The administrative officer in } \\
\text { providing a neat looking } \\
\text { examination service }\end{array}$ & 0 & 0.0 & 13 & 14.0 & 80 & 86 & 0 & 0.0 & 93 & 100 \\
\hline 2. & $\begin{array}{l}\text { Officer radiographer in providing } \\
\text { services neat }\end{array}$ & 0 & 0.0 & 4 & 4.3 & 89 & 95.7 & 0 & 0.0 & 93 & 100 \\
\hline 3. & $\begin{array}{l}\text { Radiologist Specialist in providing } \\
\text { CT Scan services neatly }\end{array}$ & 0 & 0.0 & 0 & 0.0 & 93 & 100 & 0 & 0.0 & 93 & 100 \\
\hline 4. & $\begin{array}{l}\text { Waiting room service is } \\
\text { convenient }\end{array}$ & 0 & 0.0 & 0 & 0.0 & 93 & 100 & 0 & 0.0 & 93 & 100 \\
\hline 5. & Good service layout & 0 & 0.0 & 0 & 0.0 & 93 & 100 & 0 & 0.0 & 93 & 100 \\
\hline 6. & Sophisticated CT Scan equipment & 0 & 0.0 & 0 & 0.0 & 93 & 100 & 0 & 0.0 & 93 & 100 \\
\hline 7. & $\begin{array}{l}\text { The CT scan equipment is } \\
\text { maintained }\end{array}$ & 0 & 0.0 & 1 & 1.1 & 92 & 98.9 & 0 & 0.0 & 93 & 100 \\
\hline 8. & $\begin{array}{l}\text { Room facilities are available and a } \\
\text { good dressing room. }\end{array}$ & 0 & 0.0 & 3 & 3.2 & 90 & 96.8 & 0 & 0.0 & 93 & 100 \\
\hline 9. & $\begin{array}{l}\text { CT scan service waiting room - } \\
\text { Scan is available with quite } \\
\text { complete }\end{array}$ & 0 & 0.0 & 0 & 0.0 & 93 & 100 & 0 & 0.0 & 93 & 100 \\
\hline 10. & $\begin{array}{l}\text { Adequate parking spaces are } \\
\text { available }\end{array}$ & 0 & 0.0 & 0 & 0.0 & 93 & 100 & 0 & 0.0 & 93 & 100 \\
\hline
\end{tabular}

Note: $\mathrm{SD}=$ Strongly disagree; $\mathrm{D}=\mathrm{Disagree} ; \mathrm{A}=$ Agree; $\mathrm{SA}=$ Strongly agree

Based on table 1 above could be seen that most patients had a good perception on tangible CT scan service. Tangible was a real attribute, tangible/physical and visible. This included the physical appearance of inspection room facilities, equipment and employees. There were several answers of patients who need attention by stating that the administrators look sloven (14\%), radiographer officers in providing service not look neat appearance $(4.3 \%)$. This distribution illustrate the percentage that some patients had an unfavorable perception of tangible CT scan service with the patient's symptom findings complaining to the non-performing administration officer in the registration service. The patient's perception of tangible was classified into two categories: tangible good and tangible not good. The frequency distribution of tangible perception could be seen in the following table: 
Table 2. Distribution of respondents perception to tangible aspects of CT scan services in Harapan Keluarga Hospital

\begin{tabular}{cccc}
\hline Number & Tangible aspects & Frequency & Percentage \\
\hline 1 & Good $(\geq 29,8)$ & 80 & 86 \\
2 & Not good $(<29,8)$ & 13 & 14 \\
\hline & Total & 93 & 100 \\
\hline
\end{tabular}

Table 2 shows that patients who perceive tangible was good $(86 \%)$ and who perceive not good $(14,0 \%)$. Thus, patients who perceive tangible CT scan services both more than those who perceive not good. This mean the patient's perception was appropriate than the patient's expectation of physical appearance and inspection room facilities, equipment and employees of CT scan services.

\section{Reliability}

Table 3. Distribution of patient based on realibility aspects of CT scan service in Harapan Keluarga Hospital

\begin{tabular}{|c|c|c|c|c|c|c|c|c|c|c|c|}
\hline \multirow{2}{*}{ Number } & \multirow{2}{*}{ Statement } & \multicolumn{2}{|c|}{ SD } & \multicolumn{2}{|c|}{$\mathrm{D}$} & \multicolumn{2}{|c|}{$\mathrm{A}$} & \multicolumn{2}{|c|}{ SA } & \multicolumn{2}{|c|}{ Total } \\
\hline & & $\mathrm{n}$ & $\%$ & $\mathrm{n}$ & $\%$ & $\mathrm{n}$ & $\%$ & $\mathrm{n}$ & $\%$ & $\mathrm{n}$ & $\%$ \\
\hline 1. & $\begin{array}{l}\text { Discipline time CT Scan service on } \\
\text { time }\end{array}$ & 0 & 0.0 & 40 & 43 & 53 & 57 & 0 & 0.0 & 93 & 100 \\
\hline 2. & $\begin{array}{l}\text { Officer radiographer in providing } \\
\text { services in accordance with the } \\
\text { procedure (SOP) }\end{array}$ & 0 & 0.0 & 0 & 0.0 & 93 & 100 & 0 & 0.0 & 93 & 100 \\
\hline 3. & $\begin{array}{l}\text { Queue time for CT Scan is not too } \\
\text { long }\end{array}$ & 0 & 0.0 & 53 & 57 & 40 & 43 & 0 & 0.0 & 93 & 100 \\
\hline 4. & $\begin{array}{l}\text { Radiologist Specialist in providing } \\
\text { careful CT Scan service }\end{array}$ & 0 & 0.0 & 0 & 0.0 & 93 & 100 & 0 & 0.0 & 93 & 100 \\
\hline 5. & The CT Scan service flow is clear & 0 & 0.0 & 0 & 0.0 & 93 & 100 & 0 & 0.0 & 93 & 100 \\
\hline 6. & $\begin{array}{l}\text { The results of the interpretation of a } \\
\text { radiologist are correct and correct }\end{array}$ & 0 & 0.0 & 0 & 0.0 & 93 & 100 & 0 & 0.0 & 93 & 100 \\
\hline
\end{tabular}

Note: $\mathrm{SD}=$ Strongly disagree; $\mathrm{D}=\mathrm{Disagree} ; \mathrm{A}=$ Agree; $\mathrm{SA}=$ Strongly agree

Based on table 3 above could be seen compilation of patient answers to the reliability of CT scan service was the patient agree that the radiographer officers in providing CT scan services according SOP Doctor of Radiology Specialist in providing services in accordance CT scan meticulously, and the results of the Radiologist's Doctor's interpretation were correct and correct. However, there were answers of patients who need attention concerning CT scan service reliability (43\%) CT scan service was not on time, and long queue time $(57 \%)$. In principle, the quality dimension of reliability was the endurance or reliability of service quality, the accuracy of the diagnosis and the ability to provide services that have been promised consistently and accurately.

Table 4. Distribution of respondents perception to reliability aspects of CT scan services in Harapan Keluarga Hospital

\begin{tabular}{cccc}
\hline Number & Reliability aspects & Frequency & Percentage \\
\hline 1 & Good $(\geq 17)$ & 60 & 64.5 \\
2 & Not good $(<17)$ & 33 & 35.5 \\
\hline & Total & 93 & 100 \\
\hline
\end{tabular}

Table 4 shows that patients perceive good (64.5\%) and who perceived not good $(35.5 \%)$. Thus the patient who perceived the reliability of CT scan services many perceive good compared with the perceive not good. Poor patient perceptions of $(35.5 \%)$ of service reliability reflect an experience of non-conformity of patient expectation of too long queue and time consistency.

\section{Assurance}


Table 5. Distribution of patient based on assurance aspects of CT scan service in Harapan Keluarga Hospital

\begin{tabular}{|c|c|c|c|c|c|c|c|c|c|c|c|}
\hline \multirow{2}{*}{ Number } & \multirow{2}{*}{ Statement } & \multicolumn{2}{|c|}{ SD } & \multicolumn{2}{|c|}{$\mathrm{D}$} & \multicolumn{2}{|c|}{ A } & \multicolumn{2}{|c|}{ SA } & \multicolumn{2}{|c|}{ Total } \\
\hline & & $\mathrm{n}$ & $\%$ & $\mathrm{n}$ & $\%$ & $\mathrm{n}$ & $\%$ & $\mathrm{n}$ & $\%$ & $\mathrm{n}$ & $\%$ \\
\hline 1. & $\begin{array}{l}\text { The CT scan service administration } \\
\text { officer provides the information } \\
\text { correctly }\end{array}$ & 0 & 0.0 & 14 & 15.1 & 79 & 84.9 & 0 & 0.0 & 93 & 100 \\
\hline 2. & $\begin{array}{l}\text { Officers provide action and the results } \\
\text { are easy to understand without hesitation }\end{array}$ & 0 & 0.0 & 7 & 7.5 & 86 & 92.5 & 0 & 0.0 & 93 & 100 \\
\hline 3. & $\begin{array}{l}\text { The Radiologist specialist in the service } \\
\text { conveys information about the } \\
\text { examination results correctly }\end{array}$ & 0 & 0.0 & 0 & 0.0 & 93 & 100 & 0 & 0.0 & 93 & 100 \\
\hline 4. & $\begin{array}{l}\text { The CT scan radiograhper officer is very } \\
\text { concerned about patient safety }\end{array}$ & 0 & 0.0 & 4 & 4.3 & 89 & 95.7 & 0 & 0.0 & 93 & 100 \\
\hline
\end{tabular}

Table 5 shows that distribution of answers of some patients who also need attention was the presence of administrative services CT scan provide information incorrectly (15.1\%), officers did not provide an explanation of each action $(7.5 \%)$ and radiographer officers no attention to patient safety $(4.3 \%)$. Frequency distribution of assurance perception can be seen in the following table:

Table 6. Distribution of respondents Perception to assurance aspects of CT scan services in Harapan Keluarga Hospital

\begin{tabular}{clcc}
\hline Number & Assurance aspects & Frequency & Percentage \\
\hline 1 & Good $(\geq 11.7)$ & 69 & 74.2 \\
2 & Not good $(<11.7)$ & 24 & 25.8 \\
\hline & Total & 93 & 100 \\
\hline
\end{tabular}

Table 6 shows that patients perceive the good service assurance of $(74.2 \%)$ and who perceive the service assurance was not good $(25.8 \%)$. With these data, patients who perceive the assurance of CT scan services were better than those who perceive not good. The ability of doctors in diagnosis, and convey information was a guarantee of security and trust in the quality of health services. The presence of poor perceptions of assurance reflects a doubt about the quality of CT scan services they received today and this was supported by findings of previous symptoms of patients complaining with the presence of officers who did not provide the information correctly and did not explain every action in the inspection.

\section{Responsiveness}

Table 7. Distribution of patient based on responsiveness aspects of CT scan service in Harapan Keluarga Hospital

\begin{tabular}{|c|c|c|c|c|c|c|c|c|c|c|c|}
\hline \multirow{2}{*}{ Number } & \multirow{2}{*}{ Statement } & \multicolumn{2}{|c|}{ SD } & \multicolumn{2}{|c|}{$\mathrm{D}$} & \multicolumn{2}{|c|}{ A } & \multicolumn{2}{|c|}{$\mathrm{SA}$} & \multicolumn{2}{|c|}{ Total } \\
\hline & & $\mathrm{n}$ & $\%$ & $\mathrm{n}$ & $\%$ & $\mathrm{n}$ & $\%$ & $\mathrm{n}$ & $\%$ & $\mathrm{n}$ & $\%$ \\
\hline 1. & $\begin{array}{l}\text { The radiographer officer helps the } \\
\text { patient quickly to obtain follow-up care }\end{array}$ & 0 & 0.0 & 29 & 31.2 & 64 & 68.8 & 0 & 0.0 & 93 & 100 \\
\hline 2. & $\begin{array}{l}\text { The radiographer officer cares about } \\
\text { the patient's complaints }\end{array}$ & 0 & 0.0 & 33 & 35.5 & 60 & 64.5 & 0 & 0.0 & 93 & 100 \\
\hline 3. & $\begin{array}{l}\text { The Radiology Specialist in CT scan } \\
\text { examination services cares for the } \\
\text { patient's complaints }\end{array}$ & 0 & 0.0 & 0 & 0.0 & 93 & 100 & 0 & 0.0 & 93 & 100 \\
\hline 4. & $\begin{array}{l}\text { The administrative officer will help the } \\
\text { patient quickly and friendly to get } \\
\text { service }\end{array}$ & 0 & 0.0 & 45 & 48.4 & 48 & 51.6 & 0 & 0.0 & 93 & 100 \\
\hline 5. & $\begin{array}{l}\text { Informs the availability of a suggestion } \\
\text { / complaint box for CT scan patients }\end{array}$ & 0 & 0.0 & 0 & 0.0 & 93 & 100 & 0 & 0.0 & 93 & 100 \\
\hline
\end{tabular}
Note: $\mathrm{SD}=$ Strongly disagree; $\mathrm{D}=$ Disagree; $\mathrm{A}=$ Agree; $\mathrm{SA}=$ Strongly agree 
Based on table 7 above could be seen there were some answers of patients who need to be considered related responsiveness of services that administrative Officers did not help patients quickly and friendly to get service $(48.4 \%)$, Radiographer officers did not help patients quickly to obtain advanced services $(31.2 \%)$ The radiographer officer did not care about the patient's complaints, (33.5\%) Perception responsiveness was classified into two categories: good and bad perception. Frequency distribution of responsiveness perception can be seen in the following table:

Table 8. Distribution of respondents perception to responsiveness aspects of CT scan services in Harapan Keluarga Hospital

\begin{tabular}{clcc}
\hline Number & Responsiveness aspects & Frequency & Percentage \\
\hline 1 & Good $(\geq 12.8)$ & 57 & 61.3 \\
2 & Not good $(<12.8)$ & 36 & 38.7 \\
\hline Total & 93 & 100 \\
\hline
\end{tabular}

The table 8 shows that patients perceive the responsiveness of good service $(61.3 \%)$ and who perceive the responsiveness of bad service (38.7\%). With these data, patients who perceived responsiveness of CT scan services were better than those who perceive not good. Findings that show poor perceptions of responsiveness reflect poor patient complaints, did not provide clear and understandable information and less immediate action when patients need it.

\section{Emphaty}

Table 9. Distribution of patient based on emphaty aspects of CT scan service in Harapan Keluarga Hospital

\begin{tabular}{|c|c|c|c|c|c|c|c|c|c|c|c|}
\hline \multirow{2}{*}{ Number } & \multirow{2}{*}{ Statement } & \multicolumn{2}{|c|}{ SD } & \multicolumn{2}{|c|}{$\mathrm{D}$} & \multicolumn{2}{|c|}{$\mathrm{A}$} & \multicolumn{2}{|c|}{ SA } & \multicolumn{2}{|c|}{ Total } \\
\hline & & $\mathrm{n}$ & $\%$ & $\mathrm{n}$ & $\%$ & $\mathrm{n}$ & $\%$ & $\mathrm{n}$ & $\%$ & $\mathrm{n}$ & $\%$ \\
\hline 1. & $\begin{array}{l}\text { The administration officers are very } \\
\text { friendly in CT scan service }\end{array}$ & 0 & 0.0 & 52 & 55.9 & 41 & 44.1 & 0 & 0.0 & 93 & 100 \\
\hline 2. & $\begin{array}{l}\text { The radiographer officer is very } \\
\text { friendly in CT scan service }\end{array}$ & 0 & 0.0 & 39 & 41.9 & 54 & 58.1 & 0 & 0.0 & 93 & 100 \\
\hline 3. & $\begin{array}{l}\text { CT scan service administration officers } \\
\text { are easy to contact and ask for } \\
\text { information }\end{array}$ & 0 & 0.0 & 58 & 62.4 & 35 & 37.6 & 0 & 0.0 & 93 & 100 \\
\hline 4. & $\begin{array}{l}\text { The radiographer officer always } \\
\text { answers the patient's questions with } \\
\text { pleasure }\end{array}$ & 0 & 0.0 & 10 & 10.8 & 83 & 89.2 & 0 & 0.0 & 93 & 100 \\
\hline 5. & $\begin{array}{l}\text { The Radiologist specialist lets the } \\
\text { patient wait long in the inspection } \\
\text { room }\end{array}$ & 0 & 0.0 & 69 & 74.2 & 24 & 25.8 & 0 & 0.0 & 93 & 100 \\
\hline
\end{tabular}

Note: $\mathrm{SD}=$ Strongly disagree; $\mathrm{D}=\mathrm{Disagree} ; \mathrm{A}=$ Agree; $\mathrm{SA}=$ Strongly agree

Table 9 shows that obtained accurate information from radiographer officer who always answer questions with pleasure (89.2\%), Radiology specialist doctors were not interested patients waiting long in the inspection room (74.2\%). We will ask patients who need to get attention on CT scan services: CT scan service administrators were difficult to contact and information asked for (55.9\%) CT scan service administrators were difficult to contact and information was linked (62.4\%) Findings on this subject produce information that could be accessed by existing patients promotional programs such as discounted discounts not up to the patient. This may be due to the function of the radiographer or the administrative officer at that time as a non-clinical supporter (the examiner/responsible physician) and this was of the utmost importance for the patient and the doctor or radiographer or administrative officer for information that can only be performed from a nonduplicating clinic from patient. Emphaty perception was classified into two categories: good and bad.

Table 10. Distribution of respondents perception to emphaty aspects of CT scan services in Harapan Keluarga Hospital

\begin{tabular}{clcc}
\hline Number & Empathy aspects & Frequency $(\mathrm{n})$ & Percentage $(\%)$ \\
\hline 1 & Good $(\geq 12.5)$ & 47 & 50.5 \\
2 & Not good $(<12.5)$ & 46 & 49.5 \\
\hline & Total & 93 & 100 \\
\hline
\end{tabular}


Table 10 shows that patients perceive good service empathy of $(50.5, \%)$ and who perceive emphaty not good service $(49.5 \%)$. With these data, patients who perceive empathy services CT scan was better than the perceive not good. The magnitude of perception was not good empathy indicates the need for improvement on the attention and interpersonal communication of the officer it was contained in the attitude capable and willing to provide information to the patient, and show the interest attitude with the patient, build a warm and harmonious atmosphere and sincerely do for the sake of the patient.

Table 11. Description of service quality to patient satisfaction CT scan at Harapan Keluarga Hospital

\begin{tabular}{ccccc}
\hline \multirow{2}{*}{ Number } & \multirow{2}{*}{ Service quality } & \multicolumn{2}{c}{ Patient's satisfaction } & \multirow{2}{*}{ Total } \\
\cline { 3 - 4 } & & Satisfied $(\%)$ & Not Satisfied (\%) & \\
\hline 1 & Tangible & 86.0 & 14.0 & 100 \\
2 & Realibility & 64.5 & 35.5 & 100 \\
3 & Assurance & 74.2 & 25.8 & 100 \\
4 & Responsiveness & 61.3 & 38.0 & 100 \\
5 & Emphaty & 50.5 & 49.5 & 100 \\
\hline
\end{tabular}

Table 11 shows that perceive tangible CT scan service with satisfaction (86.0\%). CT scan service was a servicing. Service was an act, perfomance, equipment, communication materials. Patients attempt to assess the quality of CT scan services from the reality they felt. Satisfaction can be due to the appearance of services and facilities was a matter that was considered important for the patient because this would determine the loyalty and subsequent customer satisfaction. However, there was a patient's dissatisfaction with the perception of empaty $(49.5 \%)$ that foury could be created with the ability of the officer in the therapeutic relationship, interpersonal communication, hospitality, modesty and patience can provide important significance for patients who feel they were regarded as valued human beings. With a lack of empathic sense of service providers can lead to uncomfortable patients and reduced satisfaction so as not to attract patients to re-select products that serviced providers.

\section{DISCUSSION}

In this study it was found that the number of men who had examined the Radiology Unit at the Harapan Keluarga Hospital was more than women. This research was supported by research conducted by Rizal in radiology department of Prof. Dr. Kandau Hospital found more male patients than female patients. In addition, the results of Qazi et al (2009) study suggest that males are more affected by illness than women because of predisposing factors in which men are more vulnerable to working outdoors than women.

Characteristics of a person greatly affect the level of satisfaction in consuming health services. The character of a person can design a pattern of perception that will determine his expectation of a service product so that a sense of satisfaction or disappointment arises when the evaluation obtained shows that the alternative has been taken lower than the conception of expectations in mind. As the level of education can affect the mindset of a person making decisions using/utilizing a health service. In the discussion of service marketing, consumer behavior is the main concern where the level of education and intelligence can influence self monitoring purchasing decisions. Customers (patients) with a higher education background tend to think about the advantages and disadvantages first before deciding to use health services compared with low educational background. Then the patient with low education background is easy to be satisfied compared with high education background because the measurement criteria received is also different.

Overall patients who performed CT scan at Harapan Keluarga Hospital were satisfied that this indicated that the value of radiology CT scan was B (Good). The highest patient satisfaction is based on Tangible indicator, that is about physical appearance and facility of inspection room, equipment and employee of CT scan service.

The patient's dissatisfaction with the perception of empaty $(49.5 \%)$ in which empathy can be created with the ability of the officer in the therapeutic relationship, interpersonal communication, hospitality, modesty and patience can provide important significance for patients who feel they are regarded as valued human beings. With a lack of empathic sense of service providers can lead to uncomfortable patients and reduced satisfaction so as not to attract patients to reselect products that service providers. Gatu ${ }^{(4)}$, said that customer satisfaction has a close relationship with quality. Quality provides an impetus to customers to forge strong bonds with the company. In the long term, such ties allow the company to understand carefully the expectations and needs of its customers. Thus, the company can increase customer satisfaction by maximizing a pleasant experience and minimizing or eliminating a less enjoyable customer experience.

Another benefit that can be gained from customer satisfaction is being able to provide a good basis for repurchase and creation of customer loyalty, as well as forming a word of mouth recommendation that is 
profitable for the company. Satisfied customers will again take advantage of the same services, otherwise dissatisfied consumers will tell others about the experience. Ultimately customer satisfaction can create loyalty or customer loyalty to the company. The company can also increase its market share by fulfilling customerdriven quality. This will give the price advantage and customer value. Customer value is a combination of benefits and sacrifices that occur when customers use a good or service to meet certain needs. When the quality is superior and the market share is great, then the profitability is assured. Thus, there is a strong link between quality and profitability ${ }^{(5)}$. Determining the level of satisfaction there are five main factors that must be considered by the company/hospital, namely:

1) Product Quality. Customers will be satisfied when the results of their evaluation indicate that the products they use are qualified.

2) Quality of service. Especially for the service industry, customers will feel satisfied if they get a good service or as expected.

3) Emotional. The customer will feel proud and gain confidence that others will be amazed by him when using products with a particular brand that are likely to have a higher level of satisfaction. Satisfaction earned is not due to the quality of the product but the social value or self esteem that makes the customer satisfied with a particular brand.

4) Price. Products that have the same quality but set a relatively cheap price will give a higher value to its customers.

5) Cost. Customers do not need to incur additional costs or do not need to waste time to get a product or service tend to be satisfied with the product or service.

A market can also be segmented based on consumer loyalty. Consumers can be loyal to brands, stores and companies. Buyers can be divided into groups according to their loyalty level. Some customers are really loyal, they always buy one brand. Other groups are rather loyal, they are loyal to two brands or more than one product or like one brand but sometimes buy another. Other buyers do not show any brand loyalty. They may want something new every time or they buy anything on sale ${ }^{(5)}$.

\section{CONCLUSION}

Characteristics of patient of CT scan service in Harapan Keluarga hospital mostly 31-40 years old and male. Higher education level and work as an entrepreneur. The perception of the patient on the quality of service with patient satisfaction CT scan service in terms of tangible, reliability, assurance, responsiveness, and emphaty service category either.

Make the rules/SOP of CT scan the patient concerning the preparedness and awareness of the officer to be available if needed by the patient, to socialize to provide information about the program of promotion activity on the patient, and integrate the training program to increase the competence of the radiographer officer and the administration of CT scan.

\section{REFERENCES}

1. Widajat Rochmanadji. Being a great and sustainable hospital. Jakarta: Gramedia Pustaka Utama; 2009.

2. PERSI-KARS, KKP-RS. Building a Hospital Patient Safety Culture (Membangun Budaya Keselamatan Pasien Rumah Sakit). Lokakarya program KP-RS. 17 Nopember 2006.

3. Qazi MA, et al. Radiological Pattern of Pulmonary Tuberculosis in Diabetes Mellitus [Internet]. 2014 [cited 2014 Dec 26]. Available from: http://kemu.edu.pk/annals/aprjun-2009/Radiological-Pattern-ofPulmonary-Tuberculosis.pdf

4. Gatu SAD. Patient Satisfaction Level Analysis Of Service Quality At Surakarta Islamic Hospital (Analisis Tingkat Kepuasan Pasien Terhadap Kualitas Pelayanan Jasa Pada Rumah Sakit Islam Surakarta). Surakarta: UNS; 2000.

5. Asmita PW. Patient Analysis About Quality of Doctor Service To Patient Loyalty in Public Policlinic of Outpatient Installation of Panti Wilasa Citarum Hospital Semarang (Analisis Pengaruh Pasien Tentang Mutu Pelayanan Dokter terhadap Loyalitas Pasien di Poliklinik Umum Instalasi Rawat Jalan Rumah Sakit Panti Wilasa Citarum Semarang). Tesis. Semarang: Program Pasca Sarjana Universitas Diponegoro; 2008. 